\title{
The Impact of Self-Access Centres in Fostering Confidence, Motivation and Autonomy to Develop Language Skills
}

\author{
Asjad Ahmed Saeed Balla \\ Al- Aflaj- Prince Suttam University, Saudi Arabia \\ Email: gamar6@hotmail.com
}

Received: 25-02-2017

Published: 01-09-2017
Accepted: 28-04-2017

doi:10.7575/aiac.ijalel.v.6n.5p.135
Advance Access Published: July 2017

URL: http://dx.doi.org/10.7575/aiac.ijalel.v.6n.5p.135

\begin{abstract}
This Paper investigates the relation between studying in Self-Access centres and learners' confidence, motivation and autonomous learning. The study based on three questions: (a) To what extent autonomous learning motivates students/users of SAC? (b) Is the use of SAC reinforcing students' confidence? (c) To what extent using SAC help in developing the students; learning skills? A questionnaire conducted to show learners; attitudes towards using SAC. The data was statistically analysed. The most important result revealed that the learners felt more confident and motivated after using SAC. Besides, there were a noticeable change in their language understanding and remarkable improvement in their language skills.
\end{abstract}

Keywords: self-access centers, confidence, motivation, autonomy

\section{Introduction}

Recently the trend of developing learners' autonomy is getting wider. The huge leap in information technology that interfere generally everywhere and the use of English as a global language specifically needs to be develop to meet this digital age requirement. In tertiary education the use of technology spread out and most of universities all over the world and in the Arab world try to get quality. The use of technology makes it essential to change methods of teaching to cope with this development.

In teaching English a lot of methods were created due to the revolution of information technology. Many teaching techniques, trends and strategies have appeared. The most important one is the autonomous learning. So, developing learners' autonomy is widespread.

\subsection{Questions of the study}

1. To what extent does autonomous learning motivate students/users?

2. Does the use of SAC reinforce students' confidence?

3. To what extent does using SAC help in developing students' learning skills?

\section{Literature Review}

Due to the development of applied linguistics, pedagogy and second language research, it becomes necessary to take the learners into consideration as a source of information and this took the research towards language learning autonomy.

(Benson 2001), Little (1995,p.179) emphasized that 'the genuinely successful learners have always been autonomous'. This shows the strong relation between performance, achievement in the language (these represent success factors) and autonomy.

Autonomy is defined by Holec (1981, p.3) as 'the ability to take charge of one's own learning'. In which he states the responsibility of the learning process on the learners' shoulders (objectives, content, progression, methods, techniques, monitoring and evaluation). These responsibilities as Holec (1981) reported in his definition consists of procedures, activities and practice of learning skills which create the term autonomous learning that came out as a result of autonomy phenomenon. Moreover, Little (1990:7) stated that the term autonomy is not representing other similar terms such as self-instruction or learning without a teacher as follows:

- autonomy is not a synonym of self-instruction

- autonomy is not limited to learn without a teacher

- In classroom context, autonomy doesn't entail an abduction of responsibility on the part of the teacher and thus it is not a matter of letting the learners get on with things as best as they can.

- On the other hand, autonomy is not something that teachers do to the learners; that is ,it is not another teaching method.

- Autonomy is not a single, easily described behaviour.

- Autonomy is not a steady state achieved by learners. 
In 2008, Cottral drew the attention to two points regarding Holec's definition of autonomy firstly, as a potential capacity that is in need for developing by the learner. Secondly, to manage one's learning attention should be given to technical aspect of learning and introduction of methodological skills.

Truly, as Onazaw (2010) argued that the term autonomy connected to many terms and concepts which confused such as self-directed learning, learners' training, independence, interdependence and individualization. (Mohamadpour, 2013)

In my opinion autonomy is one's innate/willingness aptitude/readiness for learning which needs to be developed and motivated. For developing autonomy Little (1995) debated that learning strategies and learner training play an important supporting role in the development of learner autonomy.

Nunan (2000) cited in Benson (2001), cited in Mahamadpour,2013) recorded 5 level of autonomy by which the learners gradually gets different level that helps them in enhancing and promoting autonomy within them. These five levels are as follows:

- Awareness, where learners are made aware of the pedagogical goals and content of the program to know the learning implications of pedagogical task and to identify their own learning styles.

- Involvement, where learners are involved in setting their goals from arrange of alternative options.

- Intervention, where learners are given stance to modify and adapt goals, content and learning task.

- Creation, where learners to create their goals, content and learning task.

- Transcendence, where learners go beyond the classroom learning and link it to the world beyond and this gives them a reflection opportunity when learners themselves become teachers or researchers. The importance of autonomy correlates by researchers and scholars with learning strategies, motivation cooperative learning and language proficiency.

To sum up Ur (1999:4) explains that learning skills takes place in three stages: verbalization, automation and autonomy in which the 'learners continue to use the skills on their own, becoming proficient and creative'

All above demonstrates the term autonomy and its role in language learning that leads to success which is achieved by good motivation, confidence. These are the characteristics of autonomous learners who can use them to develop and enhance their learning skills.

'learner autonomy is essentially a matter of the learner's psychological relation to the process and content of learninga is a capacity for detachment, critical reflection, decision-making and independent action' (Little,1991,p.4).

According to Little in this definition that the learner take more control of his/her own learning as he/she takes decision of the objectives, content and procedure and this doesn't mean that it is going to take place a part from the teacher.

Holec(1981,p:3 cited in Benson \&Voller,1997,p:1) defines autonomy as 'the ability to take charge of one's learning'. In addition, Benson \&Voller (1997) connected the term autonomy to five different ways which can be summarized in: situations taken by learners' on their own, skills gained by self-directed learning, learners' willingness for learning and their right to decide it.

Thanasoulas (2000), in Candy (1991, p:271) describes learning as 'a constructive process that involves actively seeking meaning from (or even imposing meaning on) events. Accordingly autonomous learners' characteristics as revealed by Rathbone (1971, p: 100, 104, cited in Candy, 1991, p: 271) are '...a self-activated maker of meaning, an active agent in his own learning process. He is not one to whom things merely happen; he is one who, by his own volition, causes things to happen. Learning is seen as the result of his own self-initiated interaction with the world'. In my opinion 'active agent' and 'own volition'are very important to each autonomous learner as they indicate readiness, confidence and strong will,which enables the learner to take these responsibilities of their own learning.

In addition to the above, there are also the affective factors that influence learning foreign language and learning in general. 'Social and psychological factors' give a more suitable description for students'reactions to the learning process. Amongst the social and affective variables at work, self-esteem and desire to learn are deemed to be the most crucial factor in the learners' ability to overcome occasional setbacks or minor mistakes in the process of learning a second or a foreign language, (Tarone\&Yule,1989,p:139). Here Tarone and Yule discussed learners' attitude and motivation. Attitudes are clarified by Wenden (1998,p:52) saying that,' learned motivations, valued beliefs, evaluations what one believes is acceptable, or responses oriented towards approaching or avoiding'.

In the same line, attitudes divided into two by Wenden that are: 'attitudes learners hold about their role in the learning process and their capability as learners (ibid, p:53); in other words learners will resist things that they don't believe in. So, their attitudes form/reform their motivations.

Dornyei (1998, p:117) describes motivation as 'one of the key factors that influence the rate and success of second or foreign language (L2) learning. Motivation provides the primary impetus to initiate learning the L2 and later the diving force to sustain the long and often tedious learning process. This shows that motivation has a great role in learning and for learners' confidence and consequently success.

An explanation is given by Gardner and MacIntyre (1993, p: 3) as they return motivation back to three components, 'motivation is comprised of three components: 'desire to achieve a goal, effort extended in this direction and satisfaction with the task'. In connection with what is written above, these three components are part of autonomous learning atmosphere and formalize autonomous learners at the same time. 
Dornyei (2001a,p:7)also defines motivation as 'why people decide to do something, how hard they are going to pursue it and how long they are willing to sustain the activity'. For more confirmation, to prove that motivation connected to success.

Dickinson (1995,p:174) reports that 'learners taking responsibility for their own learning, being able to control their own learning and perceiving that their learning successes or failures are to be attributed to their own efforts and strategies rather than to factors outside their control. It is important for the learning process in general and learning foreign language in specific that leaners should have innate willingness, motivation and confidence to perform adequately and achieve success through developing their learning skills.

Linguistic confidence described by Clement, Dornyei \& Noels, (1994, p: 422) as 'low anxious affect and high selfperceptions of L2 competence'. In this definition confidence is connected with low stress. Low stress learning environment always recommended by psycholinguists and educationalist for high learners' and learning achievement.

It has been debated that persons who have specified hard goals usually excel those who didn't choose their objectives, (Lock \& Latham 1990).This exactly what takes place in autonomous learning in which learners decide their objectives, content, procedure and take responsibilities of their own learning.

\section{Research Methodology}

A questionnaire designed by Nur (2013) was used to study the effect of a two-month English course on developing reading skills through SAC. The researcher has employed this questionnaire in this study. The respondents spent some time in a self-access centre. They were given the right to choose the time they were to spend in the self-access centre according to their scholarships. The program materials were integrated as a full English course designed to promote proficiency in general and reading skills in particular. The researcher ran a similar project in Gadarif University/Sudan. In that project, she used self-access centre to encourage learners to create their own learning space and develop confidence to improve their language skills. Being aware of using self-access centre, it was a bit easy to carry out this study in the University of Khartoum English Language Institute.

\subsection{Participants}

Participants of this study were 60 university staff members. They were in scholarship to improve their English in the English Institute/Khartoum University. For the purpose of this research paper they were advised to use the Self-Access Centre which was part of the institute.

\subsection{The Instrument}

The self-access centre or SAC consists of a service desk, a place for group discussion, a TV space, a reading corner and computers space. The researcher was the first to found a Self-Access Centre in Gedarif University, which were the first SAC in Sudanese higher education institutes and universities in 2013 in Gadarif University in Sudan. (Balla:2014)

\subsection{Reliability Statistics}

Cronbach's Alpha is used to verify the reliability of the research instrument, which was consisted of 17 statements . The result was so good as it hovers almost round 1.

\begin{tabular}{ll}
\hline Reliability Statistics & \\
\hline Cronbach's Alpha & N of Items \\
\hline .943 & 17 \\
\hline
\end{tabular}

The questionnaire consisted of two main parts; 6 questions were included in the first part about the learners' personal profile, qualifications and scholarships. Part two addressed the learners and the uses of the Self-Access Centre (SAC) in which I largely intended to investigate how the learners foster their autonomy and become confident and motivated. In this part the first question the testees were to choose either (Yes /No) option; while the second question was intended to rate the respondents' computer skills. The rest of the questionnaire consisted of 14 statements in five Liker's scale, arranged from strongly agree to strongly disagree. The statements were prepared to find out to what extent SAC was useful for them through the Self-Access Centre -as to help develop respondents autonomy and consequently be motivated and confident. Despite the fact that this study is not about reading skills, but I used some questions that dealt with reading to show that SAC could develop learning skills consecutively with the other language skills.

\section{Findings and Discussion}

The table below shows the respondents' response to the different statements of the questionnaire. The mean and the standard deviation are clear to give full picture about the respondents' response.

\begin{tabular}{lllcc}
\hline \multicolumn{1}{c}{ Statement } & N & Mean & $\begin{array}{c}\text { Std. } \\
\text { Deviation }\end{array}$ \\
\hline 1 & Did you use SAC? & 60 & 1.02 & .129 \\
2 & SAC is comfortable for self-study & 60 & 4.40 & .643 \\
3 & How do you rate your computer skills? & 60 & 3.75 & 1.144 \\
4 & The material in SAC are above my level & 60 & 2.60 & 1.196 \\
\hline
\end{tabular}




\begin{tabular}{clccc}
\hline 5 & The material in SAC are below my level & 60 & 2.70 & 1.094 \\
6 & I am encouraged to be responsible for my own learning & 60 & 4.42 & .497 \\
7 & Using multimedia motivates me to learn English & 60 & 4.22 & .825 \\
8 & I would like to continue using the SAC to improve my English & 60 & 4.75 & .474 \\
9 & After using SAC I felt more confident & 60 & 4.45 & .502 \\
10 & Using SAC is a waste of time & 60 & 1.70 & .979 \\
11 & The instructions for using the SAC are not clear & 60 & 2.02 & .813 \\
12 & I learnt new vocabulary & 60 & 4.73 & .446 \\
13 & My reading comprehension skills improved & 60 & 4.32 & .469 \\
14 & The computers are not readily available for use & 60 & 2.32 & 1.242 \\
15 & My reading fluency improved & 60 & 4.17 & .668 \\
16 & Listening while reading improved my reading speed & 60 & 4.28 & .613 \\
17 & My reading skills improved & 60 & 4.53 & .503 \\
& Valid N (listwise) & 60 & & \\
\hline
\end{tabular}

\subsection{Analysis of the questionnaire}

The following graphs give full information about the responses of the testees against each one of the statement. Graph No. (1) Shows the respondents answer to the question (Did you use the SAC)?

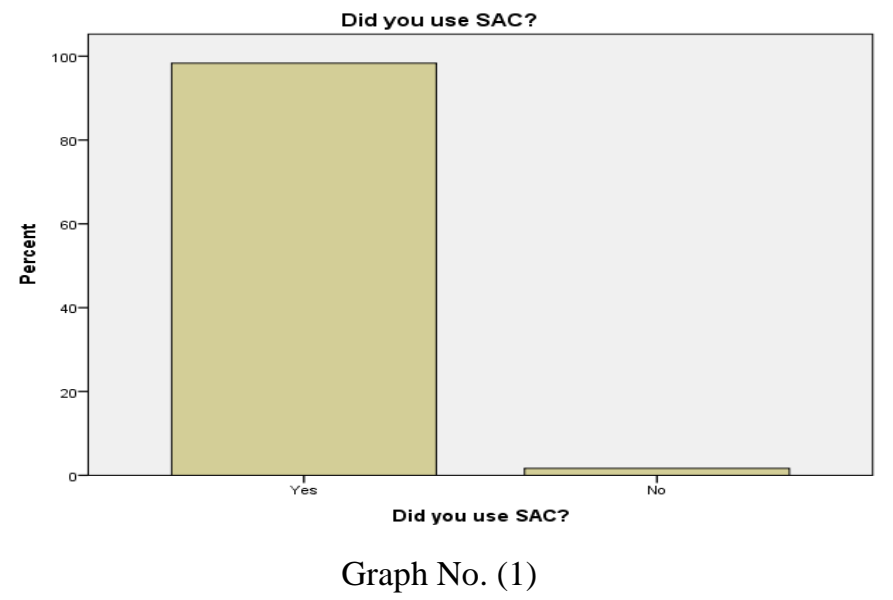

The participants were asked whether they used SAC or not. $98.5 \%$ of them used the SAC while $1.5 \%$ did not.

Graph No. 2 Shows responses for the question (whether SAC was comfortable for self-study?)

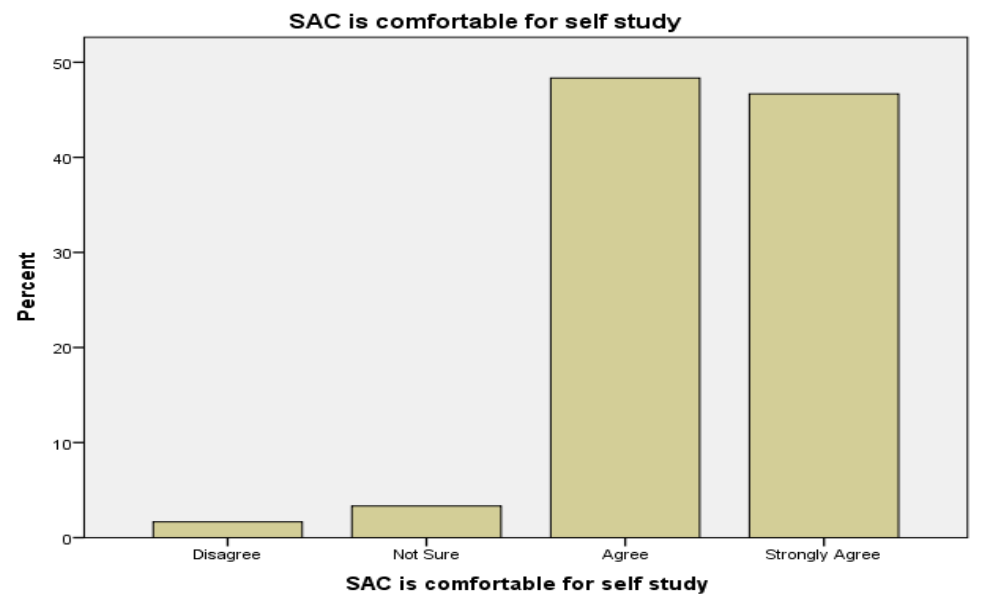

Graph No. (2)

The participants were asked whether SAC is comfortable for self-study, $45.9 \%$ strongly agreed in addition to $47.5 \%$ agreed. This indicates that the participant did not face any kind of pressure but found SAC as an attractive environment for learning. 
Graph No.3 reflects the respondents' answer for how they rated their computer skills.

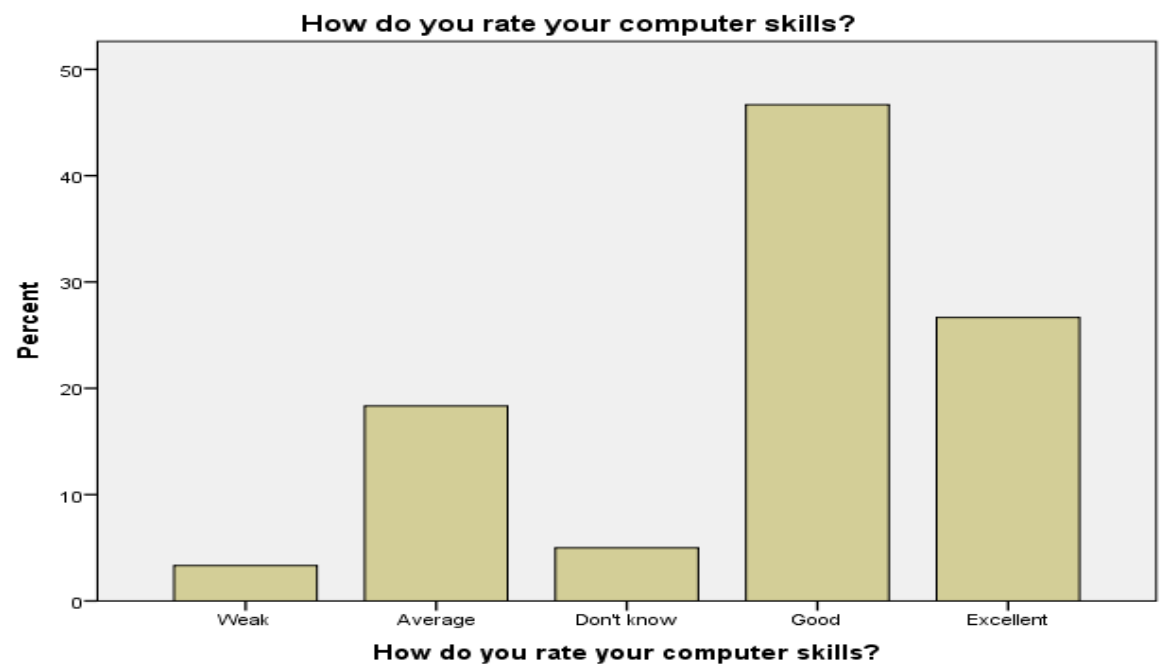

Graph No. (3)

$41.3 \%$ of the participants chose good, in addition to $27 \%$ preferred excellent in their computer skill which is a required feature should be owned by them. That means almost $68 \%$ positive response from the respondents to this item.

Graphs 4 and 5 show whether the materials are above/below the respondents' level

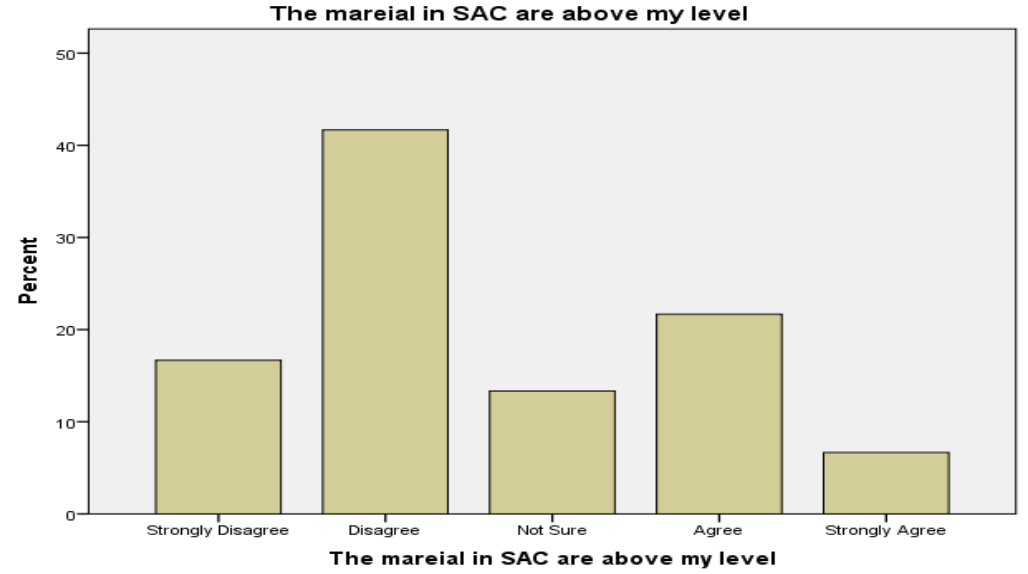

Graph No. (4)

Regarding whether the materials were above their level, $40.3 \%$ disagreed in addition to $16.1 \%$ strongly disagreed. In this case the materials can be said as perfectly designed to fit the purpose that it is designed for.

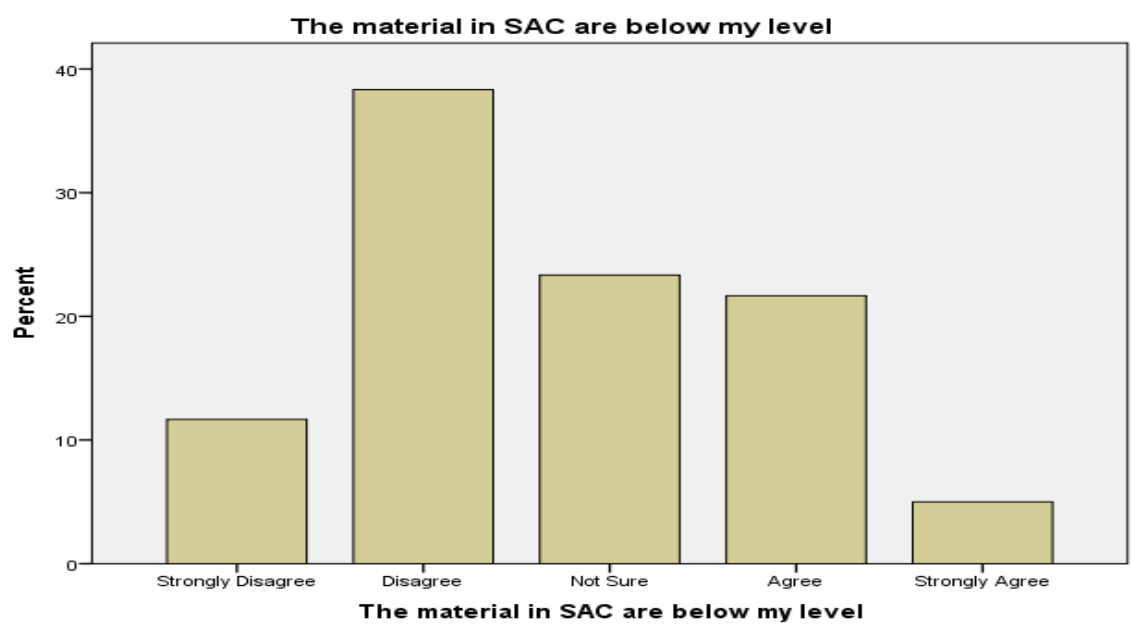

Graph No. (5)

Regarding the material that was used during the period of the course $42.4 \%$ of the respondents disagreed that the material was below their level in addition to $11.9 \%$ strongly disagreed. 
In Graph 6, the participant were encouraged to be more responsible of their own learning

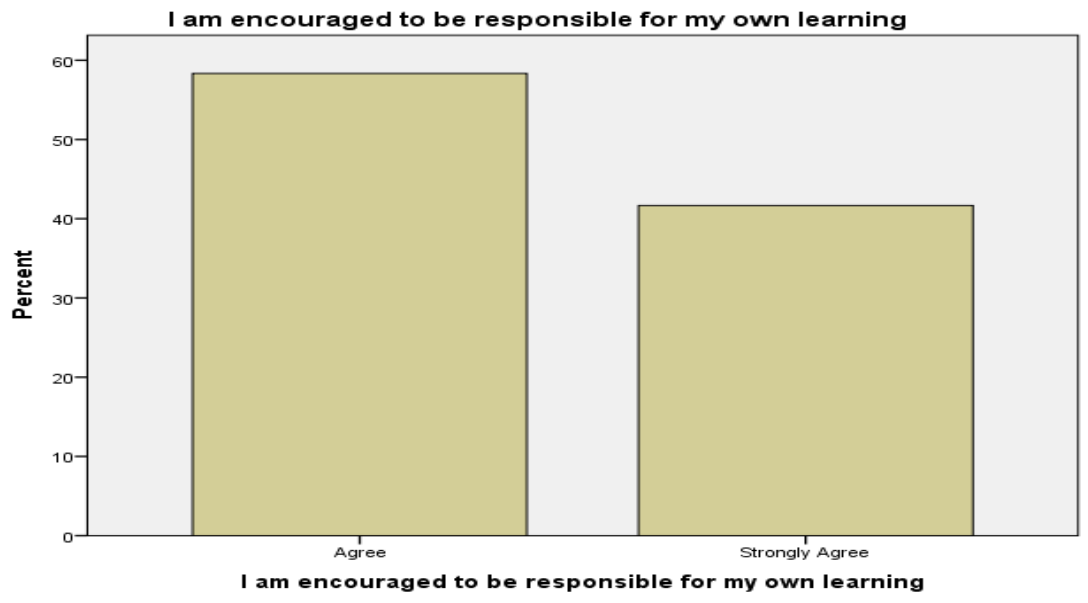

Graph No. (6)

The respondents were asked if they were encouraged to be more responsible for their own learning, $56.3 \%$ of them agreed and $39.1 \%$ strongly agreed. This shows how the participants got highly motivated, confident and comfortable to achieve success. It is almost $85 \%$ agreement response.

Graph No.7 shows how the use of multimedia motivates the respondents

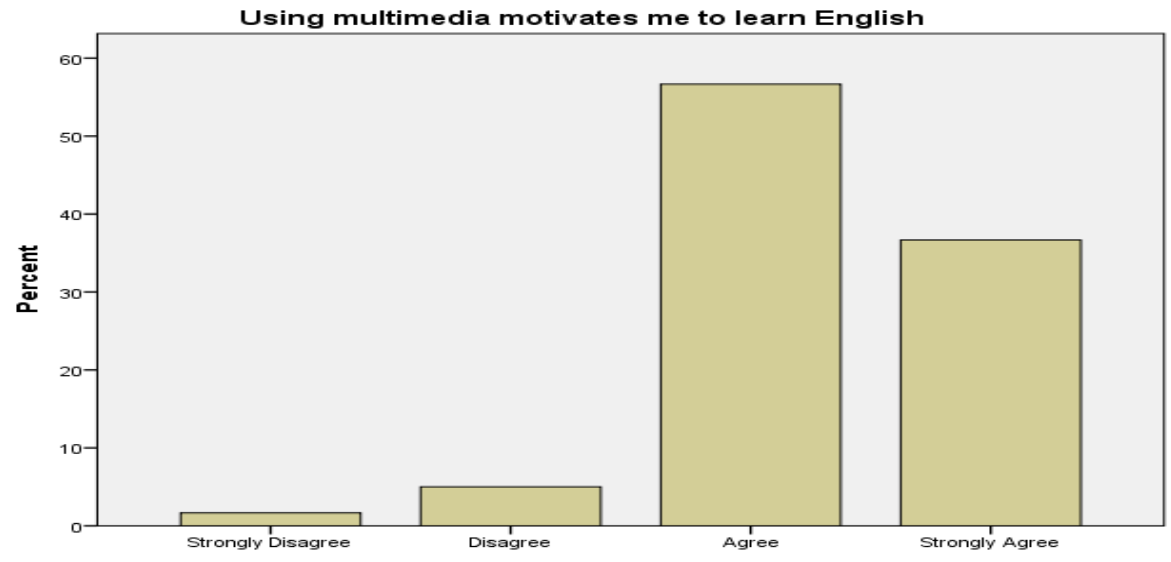

Using multimedia motivates me to learn English

Graph No. (7)

It seems that using multimedia can highly motivate the learners as it appeared clearly in their responses to this statement that $53.1 \%$ agreed in addition to $34.4 \%$ confirmed it by strongly agree.

Graph No.8 shows that whether the participants would like to continue using the SAC to improve their English.

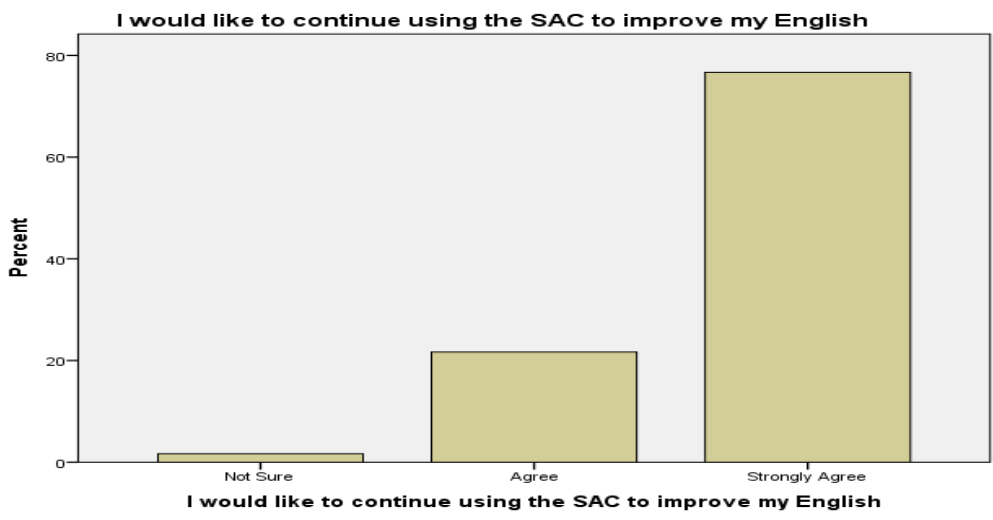

Graph No. (8)

The respondents were asked if they would like to continue using the SAC to improve their English. The response was so positive that $73 \%$ of them strongly agreed in addition to $20 \%$ agreed. This indicates that the subjects did enjoy taking 
responsibility of their own learning to the extent that they would like to continue using SAC. The total response is $93 \%$ out of $100 \%$.

Graph No.9 shows the participants' responses to whether they felt confident in learning English by their own.

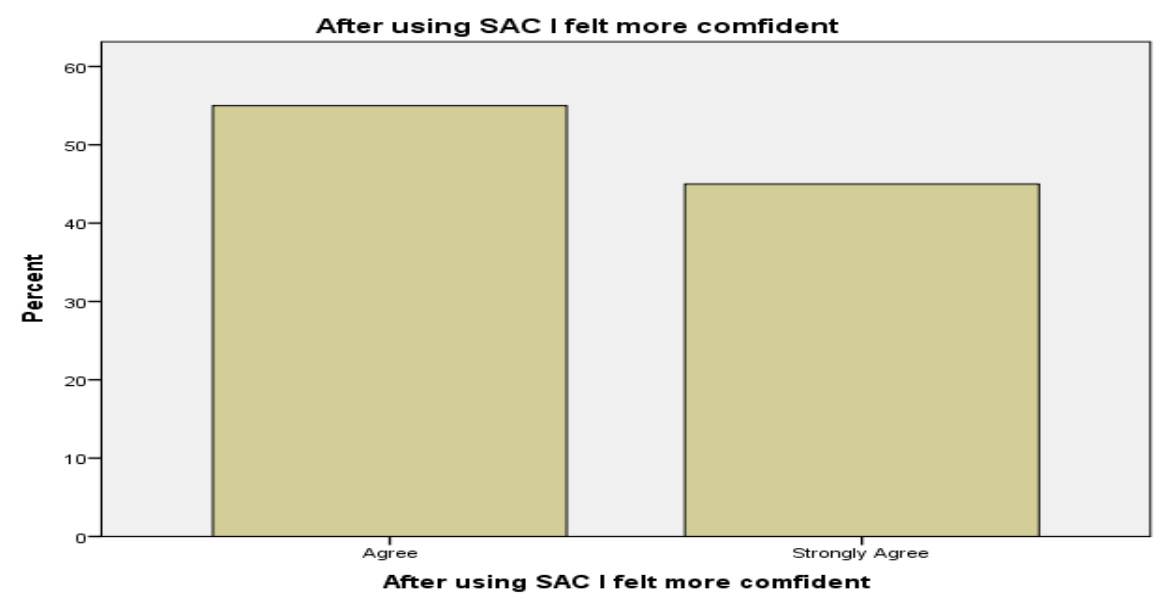

Graph No. (9)

For more emphasis on the role of SAC in learning and developing the respondents' English, they were asked whether they felt more confident to learn English on their own, $68.3 \%$ of the participants responded strongly agreed and $27 \%$ chose agreed option. So the result is so encouraging.

Graph No.10 shows the responses of whether using the SAC is a waste of time

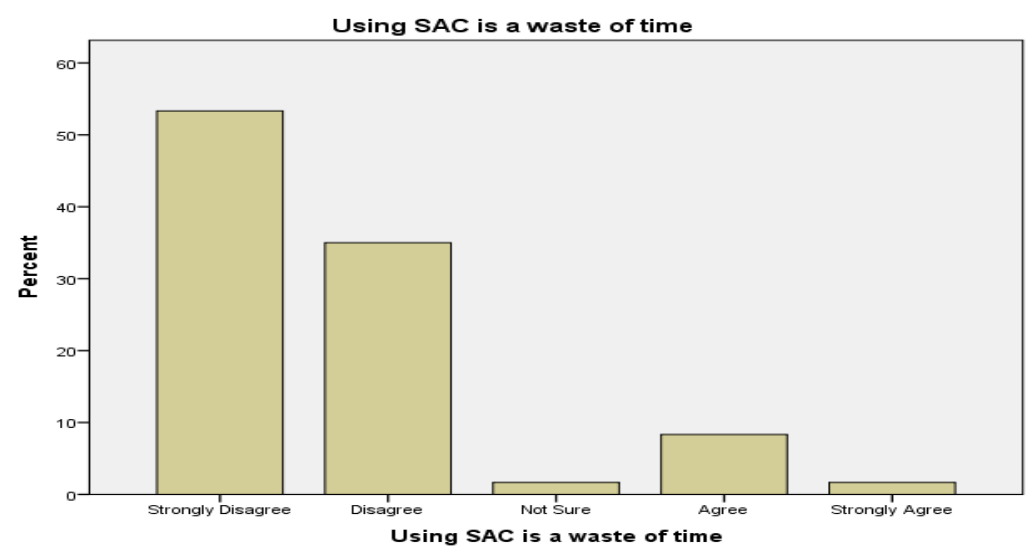

Graph No. (10)

Conversely, in Graph No.10, $52.4 \%$ strongly disagreed on that using the SAC is a waste of time in addition to $33.3 \%$ chose disagree option. It indicates that almost $87 \%$ of the learners found it useful to use the SAC to help develop their learning English skills. They believe that SAC provided them with less stress learning atmosphere that encouraged and developed their autonomous learning and consequently their confidence was increased.

Graph No.11 shows the responses towards the clarity of the instructions of using the SAC.

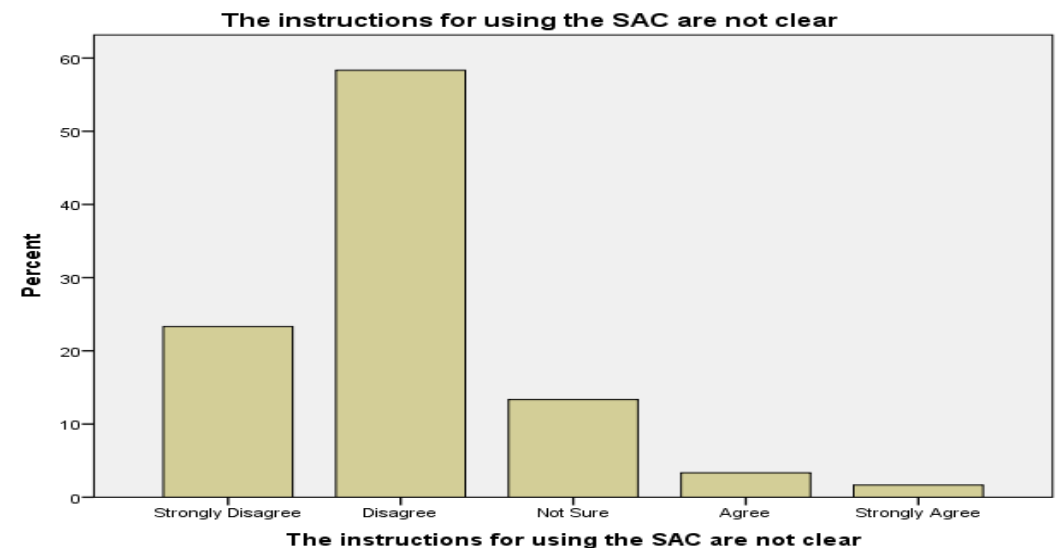

Graph No. (11) 
Lastly, the respondents were asked if the instructions of using the SAC were not clear. Graph No. 11 reveals the participants' answers.58.3\% of them disagreed in addition to $23.3 \%$ strongly disagreed. In fact, their computer skills and the easy instructions of using the SAC made it easier for them to control and manage their learning skills through the SAC.

In order to show that using SAC not only reinforced learners' confidence and motivated them but also developed their learning skills, language skills as well as their autonomy.

Tables 1, 2, 3, and 4 below show how some variables that affect the others and influence the learners' skills and abilities.

Table 1 shows that SAC is comfortable for self-study (I learnt new vocabulary)

Table 1. Crosstab

\begin{tabular}{llccc}
\hline & & \multicolumn{2}{c}{ I learnt new vocabulary } & \\
\cline { 3 - 4 } \multicolumn{1}{c}{ statement } & Agree & Strongly Agree & Total \\
\hline SAC is comfortable for self & Disagree & 1 & 0 & 1 \\
study & Not Sure & 2 & 0 & 2 \\
& Agree & 13 & 16 & 29 \\
& Strongly Agree & 0 & 28 & 28 \\
Total & & 16 & 44 & 60 \\
\hline
\end{tabular}

Table 2. Chi-Square Tests

\begin{tabular}{lccc}
\hline statement & Value & do & Asymptotic Significance (2-sided) \\
\hline Pearson Chi-Square & $23.323^{\mathrm{a}}$ & 3 & .000 \\
Likelihood Ratio & 29.698 & 3 & .000 \\
Linear-by-Linear Association & 22.290 & 1 & .000 \\
N of Valid Cases & 60 & & \\
\hline
\end{tabular}

a. 4 cells $(50.0 \%)$ have expected count less than 5. The minimum expected count is .27 .

The above table explains how it is significant to study in SAC and learn new vocabulary.

Table 3 shows that using multimedia motivates me to learn English (My reading compression skills improved)

Table 3. Crosstab

\begin{tabular}{cccc}
\hline & & \multicolumn{2}{l}{$\begin{array}{l}\text { My reading comphrension skills } \\
\text { improved }\end{array}$} \\
\cline { 3 - 4 } & statement & Agree & Strongly Agree Total \\
\hline 1 & 0 & 1 & \\
3 & 0 & 3 & \\
34 & 0 & 34 & \\
3 & 19 & 22 & 60 \\
& 41 & 19 & \\
\hline
\end{tabular}

Table 4. Chi-Square Tests

\begin{tabular}{llccc}
\multicolumn{1}{c}{ statement } & \multicolumn{3}{c}{$\begin{array}{c}\text { Asymptotic Significance (2- } \\
\text { sided) }\end{array}$} \\
\hline Pearson Chi-Square & Value & do & & .000 \\
Likelihood Ratio & $48.027^{\text {a }}$ & 3 & & .000 \\
Linear-by-Linear Association & 57.394 & 3 & .000 \\
N of Valid Cases & 25.051 & 1 & \\
\hline
\end{tabular}

Again Tables 3 and 4 above illustrate another significant relation. This relation showed an improvement in the reading comprehension due to learners get motivated when they used the multimedia in the SAC.

\section{Conclusion}

From all above, it is clear that SAC is a perfect atmosphere for learners to foster their autonomous learning. In the SAC, Learners worked on their own to develop their study skills as well as their language skills. Learners become responsible and consequently motivated to achieve success.

\section{References}

Balla, A (2014). For Learners' Autonomy Using Self-Access Centre. Global Education Review. Hong Kong: Longbridge Publishing Company. 
Benson, P \& Voller, P.(1997). Autonomy and Independence in Language Learning. London: Longman

Candy. (1991). Self-direction for lifelong Learning. California: Jossey-Bass

Clement, R., Dornyei, Z,\& Noels, K.(1994).Motivation, Self-confidence and Group Cohesion in the Foreign Language Classroom. Language Learning,44(3),417-448.

Cotterall, S. (2008). Autonomy and good language learners. In C. Griffiths. (Ed.), Lessons from good language learners (pp. 110-120). Cambridge: Cambridge University Press

Dickinson, L.(1995). Autonomy and Motivation :A Literature Review.Sustem,23(2),165-174

Dornyei, Z. (2000a) Teaching and Researching Motivation. Harlow: Longman

Dornyei,Z. (2000b). Motivational Strategies in the Language Classroom. Cambridge: Cambridge University Press

Dornyei,Z. (1998). Motivation in Second and Foreign Language Learning. CILT: CUP

Gardner,R.C.\& MacIntyre, P.D. (19930 .A student's Contributions to Second Language Learning.Part11:Affective Variables. Language Teaching, 26,1-11

Holec, H.(1981).Autonomy in Foreign Language Learning. Oxford. OUP

Little, D. (1990). Autonomy in Language Learning. In I. Gathercole (Ed.), Autonomy in Language Learning (pp. 7-15). London: CILT.

Little, D. (1995). Learning as dialogue: The dependence of learner autonomy on teacher autonomy. System, 23(2), 175181. http://dx.doi.org/10.1016/0346-251X(95)00006-6

Little, D.(199). Learner Autonomy.1: Definitions, Issues and Problems. Dublin: Authentik

Loke, E., \& Latham, G.(1990). A Theory of Goal Setting and Task Performance. Englewood Cliffs,NJ: Prentice Hall

Mohamadpou. P, (2013).Realization of Autonomy and English Language Proficiency among Iranian High School Students. Theory and Practice in Language Studies,3(7),pp. 1187-1193.

Nur, H. S. M. (2014). Promoting Reading through Self Access-Centre. Focusing on EFL Reading: Theory and Practice. Cambridge Scholar Publishing. Cambridge. Pp135-151. (edited).

Onozawa, C. (2010). Promoting autonomy in the language class: How autonomy can be applied in the language class? Retrieved from www.kyoai.ac.jp/college/ronshuu/no-10/onozawa1.pdf

Rathbone, C.H.(1971).Open Education: The Informal Classroom. New York: citation Press

Tarone, E. \& Yule, G.(1989). Focus on the Language Learner. Oxford: OUP

Ur, P. (1999). A course in language teaching: Practice and theory. Cambridge: CUP.

Wenden, A.(1998).Learner Strategies for Learner Autonomy. Great Britain: Prentice Hall. 